\title{
Antibody-Associated Lymphotoxin in Acute Infection
}

\author{
Shih-Wen Huang, Doris B. Lattos, Donald B. Nelson, \\ KenNeth Reeb, and Richard Hong \\ From the Department of Pediatrics and State Laboratory of Hygiene, University \\ of Wisconsin, Center for Health Sciences, Madison, Wisconsin 53706
}

A B S T RACT Five pediatric patients who were known to be previously healthy acutely developed lymphopenia during various viral or mycoplasma infections. In one case, fatal generalized varicella occurred and in another, severe toxic epidermal necrolysis ensued.

To further investigate this phenomenon, a study was done to determine the incidence of and elucidate the pathogenesis of lymphopenia occurring during the acute phase of viral or mycoplasma infections. Acute and convalescent sera from patients with viral or mycoplasma infection and children immunized with live measles virus were screened for lymphocytotoxic activity against normal lymphocytes by the microcytotoxicity method of Terasaki and McClelland (1). Sera with lymphocytotoxic activity were found in 15 of 48 cases of viral infections, 4 of 22 mycoplasma infections, and 1 of 11 measles virus immunized persons. All those who had sera which were cytotoxic to lymphocytes in vitro had lymphopenia. The lymphocytotoxic activity resided in 19S fractions in 8 of 11 positive sera while the remaining 3 had activity both in $19 \mathrm{~S}$ and $7 \mathrm{~S}$ fractions and could be completely removed by absorption with antilight chain antiserum. The cytotoxic activities were all complement-dependent and were greater at $37^{\circ} \mathrm{C}$ than at $4^{\circ} \mathrm{C}$.

The significance of acute acquired immunologic deficiency due to the development of antibody-associated lymphotoxin (AbAL) during acute infections is discussed and five cases having more severe clinical manifestations are presented (Appendix).

\section{INTRODUCTION}

Recently the presence of "cold lymphocytotoxin" was shown in patients with infections such as rubella, rubeola,

This paper was presented in part at the annual meeting of the Society for Pediatric Research, Atlantic City, N. J. 29 April 1971.

Dr. Huang is an Allergy Foundation Fellow.

Received for publication $20 \mathrm{July} 1972$ and in revised form 15 November 1972. and infectious mononucleosis (2). Many previously described cytotoxins related to diseases were shown to be most active at cold temperatures when tested in vitro (2). It is unknown whether such lymphocytotoxins could have any direct effect at normal body temperature. In addition, some cytotoxins effective at $37^{\circ} \mathrm{C}$ have been observed (3-6).

We recently observed four cases in our hospitals that suddenly developed lymphopenia (defined as $<1,500 /$ $\mathrm{mm}^{3}$ ) and severe clinical illness in the wake of a viral or mycoplasma infection. In a fifth, a vague febrile illness preceded by 10 days a terminal varicella infection. These observations prompted us to investigate the incidence and mechanism of lymphopenia associated with some infectious agents.

\section{METHODS}

Source of sera. In addition to the five original cases, sera were obtained from 48 cases of various viral and 22 of mycoplasma infections. Diagnosis was verified by isolation of the agents and demonstration of at least a fourfold rise in antibodies in convalescent sera. Acute sera were collected within 7 days after the onset of illness and convalescent sera were collected between 15-25 days after the onset of illness. Four age-matched control sera were obtained for each test sample. Two were obtained from cases with febrile illnesses without elevation of any viral antibodies in subsequent sera and two were from cases with various viral illnesses and subsequent elevation of antibody titers but which did not develop lymphopenia. None of these control cases were shown to have bacterial infection. The white blood cells were taken at the time when acute and convalescent sera were obtained except in two cases. Sera were also obtained from 11 individuals 2 wk after immunization with live measles virus. 22 healthy adults were also selected as normal controls.

Detection of lymphocytotoxicity. Cytotoxicity was tested by Terasaki's microdroplet method (1). Test lymphocytes, human sera (in some cases $19 \mathrm{~S}$ or $7 \mathrm{~S}$ fractions) and rabbit complement were added in that order to disposable plastic trays and incubated at $4^{\circ} \mathrm{C}$ for $3 \mathrm{~h}$ or $37^{\circ} \mathrm{C}$ for $1 \mathrm{~h}$. (Samples of the same complement source were used throughout the experiment.) Both acute and convalescent sera were tested for cytotoxicity. The lymphocytes for testing were obtained from randomly selected healthy individuals; in 
TABLE I

Infectious Agents Associated with Antibody-Associated Lymphocytotoxin (AbAL)

\begin{tabular}{lccc}
\hline \multicolumn{1}{c}{ Agents } & $\begin{array}{c}\text { No. of cases } \\
\text { studied }\end{array}$ & $\begin{array}{c}\text { No. of cases } \\
\text { with } \\
\text { lymphopenia }\end{array}$ & $\begin{array}{c}\text { No. of cases } \\
\text { with } \\
\text { AbAL }\end{array}$ \\
\hline H. simplex & 7 & 2 & 2 \\
adenovirus & 6 & 0 & 1 \\
rubella & 13 & 4 & 4 \\
mumps & 6 & 2 & 2 \\
influenza B & 4 & 1 & 1 \\
measles & 2 & 2 & 2 \\
RSV* & 8 & 2 & 2 \\
varicella & 1 & 1 & 1 \\
mycoplasma & 22 & 4 & 5 \\
unknown & 1 & 1 & 1 \\
measlesł & 11 & 1 & 1 \\
\hline
\end{tabular}

* Respiratory syncytial virus.

$\ddagger$ Immunized with live attenuated virus.

some cases autologous lymphocytes were tested also. Two panels of six cells each, obtained from a total of 12 donors, were used during the study. The criterion for positivity in our test was that three or more individual members of the donor lymphocyte panels showed more than $20 \%$ cytotoxicity as judged by eosin dye exclusion. Antilymphocyte serum was used as a positive control and always revealed more than $90 \%$ cytotoxicity to all donor cells. Each test was done in duplicate and was repeated at least three times. The result was read independently by two investigators and always agreed from time to time and between the investigators. The identity of the samples, whether lymphopenic or not, was unknown at the time of the reading. Sera from age-matched controls and 22 healthy individuals (12 males and 10 nulliparous women) were uniformly negative. It was noted that loss of cytotoxic activity occurred after repeated freezing and thawing of acute serum samples. The specific virus with which the patient was infected was added to the test mixtures in an attempt to restore the activity. This was done in two ways: (a) live virus was first incubated with normal lymphocytes for $4 \mathrm{~h}$ at $37^{\circ} \mathrm{C}$, the cells then washed, and the test was conducted as described above; (b) live virus was incubated with the appropriate test serum before addition to the test lymphocyte system. The test lymphocytes in this system were adjusted to a concentration of $1.0 \times 10^{6}$ cells/milliliter in minimal essential medium (MEM) with $10 \%$ fetal calf serum, penicillin, and streptomycin. The titer of the virus suspensions were adjusted to approximately $10^{-4}$ tissue culture dose $\left(\mathrm{TCD}_{50}\right) / 0.1$ $\mathrm{ml}$ before testing. No difference resulted from the order of addition. Virus used for testing included: rubella, mumps, influenza $\mathrm{B}$, measules, varicella, Herpes simplex, and respiratory syncytial virus. The control systems for the above tests included: (a) virus and complement only, $(b)$ virus and normal human serum only, $(c)$ virus and sera of infected but nonlymphopenic patients plus complement, $(d)$ serum from infected patients plus a virus different from the infecting agent plus complement, $(e)$ virus alone, $(f)$ complement alone. Negative results were consistently obtained with these controls.

Separation of sera into 7S and 19S fractions was accomplished by sucrose density gradient separation in a Beck- man Model L $65 \mathrm{~B}^{\mathrm{R}}$ ultracentrifuge (Beckman Instruments, Inc., Palo Alto, Calif.) (7).

$H L-A$ antigens and antibody. The HL-A antigens of the testing lymphocytes were determined by $\mathrm{Dr}$. T. Iha of the State Laboratory of Hygiene, Madison, Wisconsin, and HL-A antibody screening on the sera were performed by Dr. E. Yunis of the Immunology Division, University of Minnesota Hospital, Minneapolis, Minnesota. This test utilizes a test panel of lymphocytes obtained from 20 donors. Immunoabsorbents were prepared by conjugation of antilight chain antiserum to Sepharose 4B (Pharmacia Fine Chemicals, Inc., Uppsala, Sweden) by the method of Cuatrecasas, Wilchek, and Anfinsen (8). Immunoglobulins were absorbed from test sera by exposure to the immunoabsorbent for $60 \mathrm{~h}$ at $4^{\circ} \mathrm{C}$ using constant agitation. Quantitation of the serum immunoglobulins by single radial diffusion (9) revealed that $96 \%$ of $\operatorname{IgG}, 90 \%$ of $\operatorname{IgA}$, and $99 \%$ of $\operatorname{IgM}$ were removed. Simultaneous quantitation of albumin showed no change indicating the specificity of the immunoabsorption.

Specificity of the lymphocytotoxic effect. In order to test the specificity of the lymphocytotoxic effect, several human cell lines were utilized as target cells for 10 positive sera. Inadequate amounts precluded testing of all positive samples. The cell lines employed were HeLa, Hep-2, Wis-L (p-7, fetal epithelial cells), Wis-L ( $\mathrm{p}-24$, fetal fibroblasts), and WI-38 ( $\mathrm{p}-25$, lung fibroblasts). Cell concentrations were adjusted to $1 \times 10^{8}$ cells/milliliter for cytotoxicity tests. Viruses, serum samples, and complement were added in order as described above in the detection of lymphocytotoxicity. Subsequently, those cells were subcultured to detect any possible deleterious effect on the formation of monolayers.

Human granulocytes from peripheral blood were isolated by Böyum's method (10) from three of the donors and were also tested for cytotoxicity. Human peripheral lymphocytes from the same donors after incubation with sheep red blood cells were separated by Ficoll Hypaque (Pharmacia Fine Chemicals, Inc.) density gradient into subpopulations of rosette-forming cells (RFC) and nonrosette-forming cells (n-RFC) ${ }^{1}$ and each group was used as target cells for the above 10 positive sera.

Appropriate controls were prepared for each experiment as described above and all the tests were performed at $37^{\circ} \mathrm{C}$.

\section{RESULTS}

Screening among 48 cases with viral infections showed that 15 cases had lymphopenia while 4 of 22 cases with mycoplasma infection developed lymphopenia (Table I). No single agent seems more prone to induce lymphopenia. All of those cases which developed lymphopenia showed lymphocytotoxic activity against normal lymphocytes in their acute phase sera (Table II). Five cases (Appendix) from whom lymphocytes were obtained and tested against their own sera showed autocytotoxicity. Two cases which had peripheral blood lymphocyte counts of more than $1,500 / \mathrm{mm}^{3}$ showed only weak cytotoxic activity in their será.

\footnotetext{
${ }^{1}$ Abbreviations used in this paper: AbAL, antibody-associated lymphotoxin; CMI, cell-mediated immunity; n-RFC, nonrosette-forming cells; RFC, rosette-forming cells.
} 
TABLE II

Clinical Data of Patients with Lymphopenia

\begin{tabular}{|c|c|c|c|c|c|c|c|c|c|}
\hline Case & Age & Sex & $\begin{array}{l}\text { Offending } \\
\text { microorganism }\end{array}$ & $\begin{array}{l}\text { Clinical } \\
\text { symptoms }\end{array}$ & $\begin{array}{l}\text { Total } \\
\text { leuko- } \\
\text { cytes }\end{array}$ & $\begin{array}{l}\text { Absolute } \\
\text { lym. } \\
\text { count }\end{array}$ & $\begin{array}{l}\text { Cytotoxicity vs. panel } \\
\text { of } 6 \text { different donor } \\
\text { lymphocytes* }\end{array}$ & C. F. & $\mathrm{Ab} \ddagger$ \\
\hline 1 & 9 & $\mathbf{M}$ & mumps & parotıtis & $\begin{array}{c}11,700 \\
8,600 \S\end{array}$ & $\begin{array}{l}1,404 \\
1,750\end{array}$ & $\begin{array}{l}++,++,++,++,-,++ \\
-,-,-,-,-,-\end{array}$ & & $\begin{aligned}<1: 8 \\
1: 64\end{aligned}$ \\
\hline 2 & 14 & $\mathbf{M}$ & RSV\| & pneumonitis & $\begin{array}{l}6,800 \\
9,300\end{array}$ & $\begin{array}{l}1,360 \\
1,860\end{array}$ & $\begin{array}{l}++,++,+,++,-,- \\
-,-,-,-,-,-\end{array}$ & & $\begin{array}{l}1: 8 \\
1: 64\end{array}$ \\
\hline 3 & 12 & $\mathrm{~F}$ & H. simplex & $\begin{array}{l}\text { stomatitis, skin } \\
\text { infection }\end{array}$ & $\begin{array}{r}4,000 \\
12,000\end{array}$ & $\begin{array}{l}1,480 \\
3,560\end{array}$ & $\begin{array}{l}++,++,+++,+++,++,++, \\
-,-,-,-,-,-,\end{array}$ & & $\begin{aligned}<1: 8 \\
1: 64\end{aligned}$ \\
\hline 4 & 2 & $\mathbf{M}$ & mumps & parotitis & $\begin{array}{l}9,300 \\
8,600\end{array}$ & $\begin{array}{l}1,302 \\
2,150\end{array}$ & $\begin{array}{l}++.++,+,+,-,- \\
-,-,-,-,-,-,\end{array}$ & & $\begin{array}{l}1: 16 \\
1: 128\end{array}$ \\
\hline 5 & $\begin{array}{l}11 \\
\text { mo }\end{array}$ & $\mathbf{M}$ & varicella & skin infection & $\begin{array}{l}3,990 \\
9,800\end{array}$ & $\begin{array}{l}1,037 \\
2,250\end{array}$ & $\begin{array}{l}-,-,+,++,++,++ \\
-,-,-,-,-,-,\end{array}$ & & $\begin{array}{l}1: 16 \\
1: 128\end{array}$ \\
\hline 6 & 10 & $\mathbf{M}$ & influ. B & pneumonitis & $\begin{array}{l}12,250 \\
10,200\end{array}$ & $\begin{array}{r}945 \\
3,300\end{array}$ & $\begin{array}{l}-,++,-,+,++,++, \\
-,-,-,-,-,-,\end{array}$ & & $\begin{aligned}<1: 8 \\
1: 64\end{aligned}$ \\
\hline 7 & 10 & $\mathbf{F}$ & $\begin{array}{l}\text { measles, } \\
\text { Candida, } \\
\text { Staph aureus }\end{array}$ & scalded skin syn. & $\begin{array}{l}12,300 \\
10,700\end{array}$ & $\begin{array}{r}750 \\
4,000\end{array}$ & $\begin{array}{l}+,++,++,+,++,+, \\
-,-,-,-,-,-,\end{array}$ & & $\begin{array}{l}1: 8 \\
1: 256\end{array}$ \\
\hline 8 & 12 & $\mathbf{M}$ & $\begin{array}{l}\text { H. simplex } \\
\text { mycoplasma }\end{array}$ & $\begin{array}{l}\text { Stevens Johnson } \\
\text { syn., pneumonitis }\end{array}$ & $\begin{array}{l}7,300 \\
6,500\end{array}$ & $\begin{array}{r}500 \\
2,990\end{array}$ & $\begin{array}{l}++,++,++,++,++,++. \\
-,-,+,-,+,-,\end{array}$ & $\begin{array}{l}\text { Herpes } \\
\text { Mycoplasma }\end{array}$ & $\begin{array}{l}1: 32 \\
1: 256 \\
1: 16 \\
1: 128\end{array}$ \\
\hline 9 & 6 & $\mathbf{M}$ & measles & exanthema & $\begin{array}{l}4,000 \\
8,600\end{array}$ & $\begin{array}{r}480 \\
1,920\end{array}$ & $\begin{array}{l}+,++,++,+,++,-, \\
-,-,-,-,-,\end{array}$ & & $\begin{aligned}<1: 8 \\
1: 32\end{aligned}$ \\
\hline 10 & 3 & $\mathrm{~F}$ & RSV & bronchiolitis & $\begin{array}{l}3,900 \\
8,700\end{array}$ & $\begin{array}{l}1,499 \\
1,850\end{array}$ & $\begin{array}{l}-,++,++,++,+,- \\
-,-,-,-,-,-,\end{array}$ & & $\begin{array}{r}<1: 8 \\
1: 64\end{array}$ \\
\hline 11 & 8 & $\mathbf{M}$ & rubella & exanthema & $\begin{array}{l}5,000 \\
7,800\end{array}$ & $\begin{array}{l}1,350 \\
2,200\end{array}$ & $\begin{array}{l}-,++,-,++,+,++ \\
-,-,-,+,-,-\end{array}$ & & $\begin{array}{r}<1: 8 \\
1: 64\end{array}$ \\
\hline 12 & 13 & $\mathbf{M}$ & rubella & exanthema & $\begin{array}{l}4,500 \\
6,700\end{array}$ & $\begin{array}{l}1,125 \\
1,650\end{array}$ & $\begin{array}{l}+,+,+++,++,++,+, \\
-,-,+,-,-,-,\end{array}$ & & $\begin{array}{l}<1: 8 \\
1: 256\end{array}$ \\
\hline 13 & 17 & $\mathrm{~F}$ & $\begin{array}{l}\text { rubella, } \\
\text { herpes }\end{array}$ & $\begin{array}{l}\text { stomatitis, } \\
\text { UTI }\end{array}$ & $\begin{array}{l}7,680 \\
6,400\end{array}$ & $\begin{array}{r}230 \\
1,560\end{array}$ & $\begin{array}{l}++,+,+,+,+,+ \\
-,-,-,-,-,-,\end{array}$ & Rubella & $\begin{aligned}<1: 8 \\
1: 128\end{aligned}$ \\
\hline 14 & 10 & $\mathbf{M}$ & $\begin{array}{l}\text { ?ף } \\
\text { varicella }\end{array}$ & $\begin{array}{l}\text { disseminated } \\
\text { varicella inf. } \\
\text { (deceased) }\end{array}$ & 9,300 & 970 &,,,,,,++++++++ & & \\
\hline \multirow[t]{2}{*}{15} & 12 & $\mathbf{M}$ & $\begin{array}{l}\text { rubella } \\
\text { mycoplasma }\end{array}$ & $\begin{array}{l}\text { erythema } \\
\text { pneumonitis }\end{array}$ & 7,800 & 156 &,,,,,,+++++++++- & Rubella & $\begin{aligned}<1: 8 \\
1: 128\end{aligned}$ \\
\hline & & & & & 8,000 & 1,750 &,,,,,,------ & Mycoplasma & $\begin{array}{l}1: 16 \\
1: 256\end{array}$ \\
\hline 16 & 13 & $\mathbf{M}$ & mycoplasma & URI & $\begin{array}{l}8,300 \\
8,900\end{array}$ & $\begin{array}{r}897 \\
3,115\end{array}$ & $\begin{array}{l}+,++,++,+,-,-, \\
-,-,-,-,-,-,\end{array}$ & & $\begin{array}{l}1: 16 \\
1: 256\end{array}$ \\
\hline 17 & 15 & $\mathbf{F}$ & mycoplasma & pneumonitis & $\begin{array}{l}5,000 \\
7,300\end{array}$ & $\begin{array}{r}700 \\
1,505\end{array}$ & $\begin{array}{l}+,++,++,-,+++,+, \\
-,-,-,-,-,-,\end{array}$ & & $\begin{array}{l}1: 32 \\
1: 256\end{array}$ \\
\hline 18 & 20 & $\mathbf{M}$ & mycoplasma & pneumonia & $\begin{array}{r}15,300 \\
9,800\end{array}$ & $\begin{array}{r}918 \\
2,250\end{array}$ & $\begin{array}{l}+,+,++,++,-,- \\
-,-,-,-,-,-\end{array}$ & & $\begin{array}{l}1: 8 \\
1: 128\end{array}$ \\
\hline 19 & 31 & $\mathrm{~F}$ & mycoplasma & UR I & $\begin{array}{l}5,200 \\
7,600\end{array}$ & $\begin{array}{l}1,144 \\
3,420\end{array}$ & $\begin{array}{l}+,++.++,-,-,-, \\
-,-,-,-,-,-,\end{array}$ & & $\begin{array}{l}1: 16 \\
1: 128\end{array}$ \\
\hline 20 & 2 & $\mathrm{~F}$ & adenovirus & fever & $\begin{array}{l}5,500 \\
8,000\end{array}$ & $\begin{array}{l}1,650 \\
2,050\end{array}$ & $\begin{array}{l}++,++,-,-,++,+. \\
-,-,-,-,-,-,\end{array}$ & & $\begin{array}{l}1: 8 \\
1: 64\end{array}$ \\
\hline 21 & 15 & $\mathrm{~F}$ & mycoplasma & pneumonitis & $\begin{array}{l}8,800 \\
6,400\end{array}$ & $\begin{array}{l}1,532 \\
1,728\end{array}$ & $\begin{array}{l}++,+,++,+,-,-, \\
-,-,-,-,-,-,\end{array}$ & & $\begin{array}{l}1: 32 \\
1: 256\end{array}$ \\
\hline
\end{tabular}

* Results arranged in same order for all patients; $(-)$, no reaction; $(+), 20 \%$ cytotoxicity; $(++), 40 \%$ cytotoxicity; $(+++), 60 \%$ cytotoxicity $(++++), 80 \%$ cytotoxicity (see ref. 1 ).

‡ Complement-fixing antibody titre for the specific infectious agent.

$\S$ Second line of each entry shows values obtained during convalescence.

|| Respiratory syncytial virus.

I Preceding infection assumed; no definite agent recovered.

** Cases without lymphopenia but which showed cytotoxicity. 
Of 11 cases immunized with live measles virus, only one showed cytotoxic activity at $37^{\circ} \mathrm{C}$. However, four other cases showed cytotoxic activity at $4^{\circ} \mathrm{C}$ incubation in sera obtained 2 wk after immunization. Lymphopenia was not present. With the exception just mentioned, all the cytotoxic agents of the positive sera showed certain common characteristics: (a) optimal activity at $37^{\circ} \mathrm{C}$, (b) complement dependency, and $(c)$ ease of demonstration in acute phase sera but essentially nondetectable in convalescent sera ( 0 in $12,1+$ in 3 ).

Reactivation of the cytotoxic activity of the acute sera was observed after addition of viruses to test cells by either of the methods described above. These results are shown on Table III. It can be seen that increased cytotoxicity was obtained after addition of appropriate viruses in nearly all cases and frequently the return was equal to or greater than the original activity. Cytotoxicity could not be produced in any of the convalescent sera by the addition of virus.

In an attempt to further define the nature of the serum factor(s), immunoglobulins were removed by incubation with an antilight chain immunoabsorbent. Absorbed sera did not show lymphocytotoxic activity, and the addition of viruses had no effect on reconstitution of the absorbed sera.

11 of the positive sera were separated into $7 \mathrm{~S}$ and $19 \mathrm{~S}$ fractions and the fractions were tested for cytotoxicity as described above. In all serums, the cytotoxicity seemed to reside in the $19 \mathrm{~S}$ fraction and in only three sera was there activity in the $7 \mathrm{~S}$ fraction.

None of the human tissue culture cell lines in suspension demonstrated cellular damage as shown by eosin dye exclusion tests during microcytotoxicity tests and further, there were no deleterious effects which prevented formation of monolayers. Treated cell lines were identical to controls over a period of a $72 \mathrm{~h}$ observation. In addition, no cytotoxic effect was demonstrable against granulocytes obtained from three normal donors.

When the cytotoxicity test was done on RFC's ( $T$ cells) and n-RFC's ( $B$ cells) (11-13) from peripheral blood of three donors, a significant cytotoxic effect from + to +++ was noted for RFC's ( $T$ cells) for all three donors by each of 10 positive sera. Only minimal cytotoxicity (maximum +1 ) was seen in 3 of 10 positive sera for n-RFC's ( $B$ cells). In addition, when positive serums were added to lymphocytes in a subcytotoxic concentration ( $1: 20$ final dilution), a $30-40 \%$ inhibition of sheep cell rosette formation was observed.

\section{DISCUSSION}

Lymphocytotoxins or lymphocytotoxic antibodies were described in sera from allografted animals several years ago $(14,15)$. In 1964 a satisfactory microdroplet method was developed (1) and it was soon established that lymphocytotoxin appeared in human sera in the course of various clinical conditions $(2-6,16-27)$.

Some of the previously described lymphocytotoxins showed cytolytic activity best at cold temperatures $\left(15^{\circ} \mathrm{C}\right)$ and complement dependency. Some were associated with various autoantibodies (16) or with certain types of HL-A antigens (22). Others have been described in association with certain phases of different clinical diseases $(2-6,19)$. The clinical significance of the "cold toxins" at body temperatures, however, is not yet well understood, although it has been speculated that they might be biologically active in a way similar to cryoglobulins or cold autohemolysin anti-i (28). For reasons of clarity, we refer to our serum factor as antibody-associated lymphotoxin (AbAL). This avoids confusion with lymphocytotoxins which are lymphokines produced as part of a cell-mediated immune reaction (29).

Screening of cases whose specimens were referred for virological studies showed that 15 out of 48 had lymphopenia (absolute count of lymphocytes less than $1,500 / \mathrm{mm}^{3}$ ) during certain periods of acute infections. The lymphopenia in all cases was correlated with the presence of AbAL and the return to normal (usually within 2-3 wk) was associated with loss of lymphocytotoxic activity of the sera. As indicated in Table II, there were only two patients who did not have lymphopenia by the above criteria, yet their sera had cytotoxic activity. This might be due to the fact that their counts were not taken until several days after the acute sera had been drawn. Most of the convalescent sera showed only weak or no cytotoxic activity.

The fact that diminution of the activity of the sera was observed after absorption with antilight chain antibody suggested that the cytotoxic factor was immunoglobulin in nature. Further studies demonstrated that the cytolytic action could be produced by adding virus, serum containing its specific antibody and complement to the testing lymphocytes. The gradual loss of this cytotoxic activity after the freezing and thawing of the positive sera could be interpreted as due to either the instability of antibody or possible destruction of virus. Addition of appropriate virus restored this loss. The mechanism for this phenomenon remains obscure, however. It is possible that viral antigen-antibody complexes were disrupted by freeze-thaw and new virus was required for new complex formation. Perhaps new virus altered the target lymphocytes, rendering them more susceptible to lysis. The fact that only the virus which originally infected the patient was effective in this regard rules out a nonspecific cytotoxic effect of viral origin. These observations suggest that a number of unique interactions between host lymphocytes, humoral antibody, and infecting virus may be required for lym- 
TABLE III

Restorative Effect of Virus on Lymphocytotoxicity

\begin{tabular}{|c|c|c|c|c|c|c|c|c|}
\hline \multirow[b]{2}{*}{ Case } & \multirow[b]{2}{*}{ Virus } & \multirow[b]{2}{*}{ Condition } & \multicolumn{6}{|c|}{ Donor } \\
\hline & & & 1 & 2 & $\begin{array}{c}3 \\
\text { (degree of } \\
\end{array}$ & $\begin{array}{c}4 \\
\text { ytotoxicity) } \\
\end{array}$ & 5 & 6 \\
\hline \multirow[t]{3}{*}{1} & mumps & $A^{*}$ & $++\|$ & ++ & ++ & ++ & - & ++ \\
\hline & & $\mathrm{F}-\mathrm{T} \ddagger$ & - & - & - & - & - & - \\
\hline & & $F-T+V \S$ & + & ++ & - & - & - & + \\
\hline \multirow[t]{3}{*}{2} & RSV & A & ++ & ++ & + & ++ & - & - \\
\hline & & $\mathrm{F}-\mathrm{T}$ & - & - & - & - & - & - \\
\hline & & $\mathrm{F}-\mathrm{T}+\mathrm{V}$ & +++ & + & - & - & - & - \\
\hline \multirow[t]{3}{*}{3} & H. simplex & A & ++ & ++ & +++ & +++ & ++ & ++ \\
\hline & & $\mathrm{F}-\mathrm{T}$ & - & - & - & - & - & - \\
\hline & & $F-T+V$ & ++ & ++ & + & + & - & - \\
\hline \multirow[t]{3}{*}{4} & mumps & A & ++ & ++ & + & + & - & - \\
\hline & & $\mathrm{F}-\mathrm{T}$ & - & - & - & - & - & - \\
\hline & & $F-T+V$ & - & + & - & + & ++ & - \\
\hline \multirow[t]{3}{*}{5} & varicella & A & - & - & + & + & + & + \\
\hline & & $\mathrm{F}-\mathrm{T}$ & - & - & - & - & - & - \\
\hline & & $F-T+V$ & - & - & - & +++ & ++ & + \\
\hline \multirow[t]{3}{*}{6} & influ. B & A & - & ++ & - & + & ++ & ++ \\
\hline & & $F-T$ & - & - & - & - & - & - \\
\hline & & $F-T+V$ & - & +++ & - & + & + & $++t$ \\
\hline \multirow[t]{3}{*}{7} & measles & A & ++ & ++ & + & ++ & + & - \\
\hline & & $\mathrm{F}-\mathrm{T}$ & - & - & - & - & - & - \\
\hline & & $F-T+V$ & ++ & ++ & - & ++ & ++ & - \\
\hline \multirow[t]{3}{*}{8} & mycoplasma & A & ++ & ++ & ++ & $+t$ & ++ & ++ \\
\hline & & $\mathrm{F}-\mathrm{T}$ & - & - & - & - & - & - \\
\hline & & $F-T+V$ & +++ & ++ & - & + & - & + \\
\hline \multirow[t]{3}{*}{9} & measles & A & + & ++ & ++ & + & ++ & - \\
\hline & & $F-T$ & - & - & - & - & - & - \\
\hline & & $F-T+V$ & - & ++ & + & - & + & - \\
\hline \multirow[t]{3}{*}{10} & RSV & A & - & + & + & + & + & - \\
\hline & & $F-T$ & - & - & - & - & - & - \\
\hline & & $F-T+V$ & - & - & + & + & - & - \\
\hline \multirow[t]{3}{*}{11} & rubella & A & - & ++ & - & ++ & + & ++ \\
\hline & & $\mathrm{F}-\mathrm{T}$ & - & - & - & - & - & - \\
\hline & & $F-T+V$ & - & + & - & ++ & - & + \\
\hline \multirow[t]{3}{*}{12} & rubella & A & + & + & +++ & + & + & + \\
\hline & & $\mathrm{F}-\mathrm{T}$ & - & + & + & - & - & - \\
\hline & & $F-T+V$ & - & + & + & + & - & - \\
\hline \multirow[t]{3}{*}{13} & H. simplex & A & ++ & + & - & + & + & + \\
\hline & & $\mathrm{F}-\mathrm{T}$ & - & - & - & - & - & - \\
\hline & & $\mathrm{F}-\mathrm{T}+\mathrm{V}$ & + & - & - & + & - & - \\
\hline \multirow[t]{3}{*}{14} & varicella & A & ++ & + & + & + & ++ & + \\
\hline & & $F-T$ & - & - & - & - & - & - \\
\hline & & $F-T+V$ & ++ & + & ++ & +++ & ++++ & $++t$ \\
\hline \multirow[t]{3}{*}{15} & mycoplasma & A & $+t$ & ++ & + & + & ++ & + \\
\hline & & $\mathrm{F}-\mathrm{T}$ & - & - & - & - & - & - \\
\hline & & $F-T+V$ & + & + & - & - & - & - \\
\hline
\end{tabular}

*A, fresh serum specimen.

$\ddagger F-T$, serum after freeze and thaw five times.

$\S \mathrm{F}-\mathrm{T}+\mathrm{V}$, virus added to serum after freeze and thaw.

$\|+, 20 \%$ cytotoxicity,,$++++>80 \%$ cytotoxicity; $(-)$, no reaction.

If Respiratory syncytial virus. 
phopenia to result. No single agent seems more prone to induce lymphopenia.

We also demonstrated that the cytotoxic activity mainly resides in the $19 \mathrm{~S}$ fraction of the sera; three sera also showed some activity in the $7 \mathrm{~S}$ fraction. The convalescent sera failed to demonstrate significant cytotoxic activity. Additionally, the possibility of a "blocking factor" in the convalescent sera has not been ruled out. It is possible that $\operatorname{IgM}$ was the major antiviral antibody in the acute phase while in the convalescent phase IgG was predominant.

At the time when the cytotoxic agent was demonstrable in the serum sample, titers of complement-fixing antivirus antibody were $1: 8$ or less. Also, during convalescence, when complement-fixing titers had risen fourfold or more, virus-serum cytotoxicity effects had disappeared. Thus, the agent seems different from classic antibody as detected by usual complement-fixing methods. However, the sedimentation characteristics and the association with light chain determinants lead us to believe that the agent is an antibody.

Human cell lines other than lymphocytes were also tested in the same cytotoxicity system but there was no cytotoxic effect seen among those cell lines nor with granulocytes. In preliminary tests, the cytotoxic activity seemed to be greater for $\mathrm{T}$ lymphocytes than $\mathrm{B}$ lymphocytes. Further effects upon cell-mediated immunity (CMI) function are still under study but if these results are substantiated they may bear upon the transient anergy noted in various viral infections $(30)$.

There is a form of immunological deficiency in humans reported by Kretschmer, Janeway, and Rosen (26) in which a patient was noted to have dysgammaglobulinemia and also lymphopenia due to the presence of lymphocytotoxic antibody. As expected, she manifested failure of lymphocyte-dependent functions including allograft rejection, delayed hypersensitivity, and immunologic memory. It is interesting to note that her serum lymphotoxic antibody was associated with $\gamma$-A globulin and that bouts of recurrent profound lymphopenia followed infections. We have observed a similar course of events in a patient with thymic deficiency and lymphopenia. Viral infections associated with $\mathrm{AbAL}$ formation resulted in complete absence of lymphocytes and on at least two occasions, Pneumocystis pneumonia. After successful therapy the lymphocyte count returned to its preillness state and $\mathrm{AbAL}$ was no longer demonstrable. $^{2}$

The cytotoxic activity described in our studies was not due simply to HL-A antibody activity. Our cases differ from individuals possessing HL-A antibodies in a number of ways. There was no history of previous

${ }^{2}$ Levy, R. L., S.-W. Huang, and R. Hong. Manuscript in preparation. transfusion or allogeneic stimulation. Serum cytotoxic activity was present only transiently-i.e., in the acute stage but not in convalescent sera. Addition of viruses restored cytotoxic activity. Finally, no HL-A antibody activity could be demonstrated in our cytotoxic sera when tested against a panel of 20 donors. The number of donors is admittedly small, however.

In two cases, the development of lymphopenia resulted in severe clinical symptoms (Case 14 and 7 of Table II) ; both patients had been known to be healthy previously. Case 14 succumbed to disseminated varicella. He had had live virus immunizations previously without any complication. Postmortem studies showed the depletion of small lymphocytes from the lymph nodes. Unfortunately, the thymus was not studied and the cause of the previous infection was not clear. Case 7 apparently was exposed to measles resulting in elevation of measles antibody, although she did not demonstrate clinical disease. While she was having lymphopenia she was infected with Candida albicans and a Staphylococcus aureus of an unusual phage type. She developed the scalded skin syndrome which is extremely rare in this age group. The restriction of the scalded skin syndrome to the very young in human and experimental situations suggests some immunologic compromise as important in its etiology. In the two cases just mentioned, it is postulated that $\mathrm{AbAL}$ induced sufficient impairment of immunity to allow the unusual expression of a superimposed infectious agent. Recently, Dudding and his associates ( 31 ) reported three fatal cases of pneumonia associated with adenovirus type 7 . The patients were previously in good health but succumbed to death after a brief fulminant illness. One striking feature of those cases was persistent lymphopenia. Although the superimposition of other bacterial infection or other viral infections was not clear in their cases, the clinical picture was very similar to acute acquired immunologic deficiency which occurred in our two cases.

Three other patients had less severe illnesses as compared to the above cases and recovered. All their lymphocyte counts returned to normal with the disappearance of AbAL except one patient, Case 15, who had sustained lymphopenia for nearly 2 mo. It was not clear whether this patient had persistence of virus-antibody complex in the circulation or chronic viremia, but his course was unusually prolonged. Fortunately, he recovered without any further clinical complications.

Only one case developed AbAL after live measles virus immunization among 11 cases studied. She had an uneventful clinical course throughout the observation. Four cases, however, did have lymphocytotoxic factor optimally active at $4^{\circ} \mathrm{C}$. This finding is consistent with the observations of Kreisler, Hirata, and Terasaki (19). Unfortunately, it was not possible to 
compare the effect of natural measles infections with live virus vaccination as regards the development of AbAL.

Host responses to viral infections have been reviewed extensively recently (30). Some important biological phenomena associated with viral infections such as tissue injured mediated by antiviral antibody through a complement effector system (32), inhibition of in vitro lymphocyte blast transformation, abrogation of delayed type hypersensitivity (30) are well established by many studies. The basic mechanism for such phenomena remains unclear. Factors such as the possible existence of virus receptors on cell membranes as well as the role of HL-A antigen in humans may play an important role. By whatever mechanism, the destruction of target lymphocytes as a consequence of viral infection may set the stage for serious clinical disease.

\section{ACKNOWLEDGMENTS}

We would like to thank Miss Virginia Allen of the Wisconsin State Laboratory of Hygiene for supply of mycoplasma and patient sera. We are indebted to Mrs. Jean Gordon for aid in supplying us with normal donor cells and to Mrs. Susan Klein in the preparation of this manuscript. We would also like to thank the many physicians of the Madison community for patient referral and clinical data.

This paper was supported by grants from the U. S. Public Health Service (AM-15086) and the American Cancer Society (IN-35 K 43).

\section{APPENDIX}

Case 7, a 10-yr-old female, was admitted in a semicomatous state after a short febrile illness. She had a generalized skin eruption with whitish-gray papules and an extensive denudation with a positive Nikolsky's signa picture of scalded skin syndrome (toxic epidermal necrolysis). Candida albicans was cultured from the tongue and vagina. Skin cultures yielded Staphylococcus aureus, coagulase positive, phage type 187 . There was no significant lymphadenopathy. Her absolute lymphocyte count was 750/ $\mathrm{mm}^{3}$ on admission and $1,750 / \mathrm{mm}^{3}$ on the 4th hospital day. She was discharged 2 wk later after a complete recovery. She had been exposed to measles before the acute illness and acquired an elevated antibody titer without clinical disease.

Case 8, a 12-yr-old male, had a history of a febrile illness for a week followed by a generalized skin rash. $\mathrm{He}$ also had conjunctivitis, stomatitis, and left lower lobe pneumonia. His absolute lymphocyte count was $500 / \mathrm{mm}^{3}$ on admission and $2,576 / \mathrm{mm}^{3}$ on the 10th hospital day. He had an initial elevation of Herpes simplex antibody titer and mycoplasma complement-fixing titer was elevated during the recovery.

Case 13, a 17-yr-old female, had a prior mild febrile course for 7 days and then developed a high fever, abdominal pain, and stomatitis. Herpes virus was isolated from the lesion and urine culture grew micrococci. She was exposed to rubella without developing any rash but the antibody titer became elevated. Her absolute lymphocyte count was $230 / \mathrm{mm}^{3}$ and returned to $1,560 / \mathrm{mm}^{8}$ on the 4th hospital day.
Case 14, a 10-yr-old boy, was admitted in a state of shock with a history of minor symptoms for 10 days. Subsequently, he was found to have myocarditis, pericarditis, pleural effusion, hepatic disease, and possible central nervous system lesions. He also developed disseminated intravascular coagulopathy and expired on the 7th day. Postmortem findings revealed that he had disseminated varicella. The virus was isolated from the lung, spleen, and liver. His absolute lymphocyte count was $1,000 / \mathrm{mm}^{3}$ on admission and then dropped to $960 / \mathrm{mm}^{3}$. Unfortunately, histological study of the thymus was not done. Although he was previously well and his vaccination history was uneventful, he was known to be exposed to varicella during his early illness and he never developed skin manifestations.

Case 15 , a 12 -yr-old male, was admitted with a generalized maculopapular rash after a minor illness for 2 wk. Chest $\mathrm{X}$ ray showed viral pneumonitis. Profound lymphopenia with a range of $73 / \mathrm{mm}^{3}-336 / \mathrm{mm}^{3}$ was noted and it was 2 mo before his count was up to normal. His sister had received a rubella vaccine before his illness and had an elevated titer of mycoplasma during the recovery. He did not have any clinical problems while he had prolonged lymphopenia.

These five cases were previously healthy and all had complete immunizations without any problems. Most of the immunological tests done during hospitalizations were normal except for slightly low IgM and complement in Case 14 and a low phytohemagglutinin transformation in Case 7.

\section{REFERENCES}

1. Terasaki, P. I., and J. D. McClelland. 1964. Microdroplet assay of human serum cytotoxins. Nature (Lond.). 204 : 998.

2. Mottironi, V. D., and P. I. Terasaki. 1970. Lymphocytotoxins in disease. I. Infectious mononucleosis, rubella and measles. Histocompatibility testing. Munksgaard, Copenhagen, 301.

3. Mittal, K. K., M. R. Mickey, D. P. Singal, and P. I. Terasaki. 1968. Serotyping for homotransplantation. XVIII. Refinement of microdroplet lymphocyte cytotoxicity test. Transplantation. 6: 913.

4. Stastny, P., and M. Ziff. 1971. Antibodies against cell membrane constituents in systemic lupus erythematosus and related diseases. I. Cytotoxic effect of serum from patients with systemic lupus erythematosus for allogeneic and for autologous lymphocytes. Clin. Exp. Immunol. 8: 543.

5. Stastny, P., and M. Ziff. 1971. Lymphocyte and platelet autoantibodies in S.L.E. Lancet. 1: 1239.

6. Butler, W. T., J. T. Sharp, R. D. Rossen, M. D. Lidsky, K. K. Mittal, and D. A. Gard. 1972. Relationship of the clinical course of systemic lupus erythematosus to the presence of circulating lymphocytotoxic antibodies. Arthritis Rheum. 15: 231.

7. Franklin, E. C., H. R. Holman, H. J. Müller-Eberhard, and H. G. Kunkel. 1957. An unusual protein component of high molecular weight in the serum of certain patients with rheumatoid arthritis. J. Exp. Med. 105: 425.

8. Cuatrecasas, P., M. Wilchek, and C. B. Anfinsen. 1968. Selective enzyme purification by affinity chromatography. Proc. Natl. Acad. Sci. U. S. A. 61: 636.

9. Mancini, G., J-P Vaerman, A. O. Carbonara, and J. F. Heremans. 1963. A single-radial-diffusion method for the immunological quantitation of proteins. In Protides of the Biological Fluids. Proceedings of the Twelfth 
Colloquium, Bruges. H. Peeters, editor. Elsevier Publishing Co., Inc., New York. 370.

10. Böyum, A. 1968. Isolation of mononuclear cells and granulocytes from human blood. Scand. J. Clin. Lab. Invest. 21 (Suppl. 97) : 77.

11. Paramichael, M., and E. J. Holborow. 1972. Subpopulation of human peripheral blood lymphocytes distinguished by combined rosette formation and membrane immunofluorescence. Lancet. $2: 64$.

12. Jondal, M., G. Holm, and H. Wigzell. 1972. Surface markers on human $\mathrm{T}$ and $\mathrm{B}$ lymphocytes. J. Exp. Med. $136: 207$.

13. Wybran, J., M. C. Carr, and H. H. Fudenberg. 1972. The human rosette-forming cell as a marker of a population of thymus-derived cells. J. Clin. Invest. 51: 2537.

14. Amos, D. B., P. A. Gorer, B. M. Mikulska, R. E. Billingham, and E. M. Sparrow. 1954. Antibody response to skin homografts in mice Br.J. Exp. Pathol. 35: 203.

15. Walford, R. L., R. E. Anderson, P. K. Carter, and F. Mihajlovic. 1962. Leukocyte antibodies in inbred strains of guinea pigs following first and second set skin homografts. J. Immunol. 89: 427.

16. Terasaki, P. I., V. D. Mottironi, and E. V. Barnett. 1970. Cytotoxins in disease. Autocytotoxins in lupus. $N$. Engl. J. Med. $283: 724$.

17. Williams, R. C., Jr., J. D. Emmons, and E. J. Yunis. 1971. Studies of human sera with cytotoxic activity. J. Clin. Invest. 50: 1514.

18. Mittal, K. K., R. D. Rosen, J. T. Sharp, M. D. Lidsky, and W. T. Butler. 1970. Lymphocyte cytotoxic antibodies in systemic lupus erythematosus Nature (Lond.). 225 : 1255 .

19. Kreisler, M. J., A. A. Hirata, and P. I. Terasaki. 1970. Cytotoxin in disease. III. Antibodies against lymphocytes produced by vaccination. Transplantation. 10: 411 .

20. Kreisler, M. J., S. Naito, and P. I. Terasaki. 1971. Cytotoxins in disease. V. Various diseases. Transplant. Proc. 3: 112.

21. Butler, W. T., J. T. Sharp, R. D. Rossen, K. K. Mittal, and M. D. Lidsky. 1971. Lymphocytotoxic antibodies in systemic lupus erythematosus in relation to signs and symptoms of disease Arthritis Rheum. 14: 373.

22. Terasaki, P. I., M. R. Mickey, J. N. Yamazaki, and D. Vredevoe. 1970. Maternal-fetal incompatibility. I. Incidence of HL-A antibodies and possible association with congenital anomalies. Transplantation. 9: 538.

23. Walford, R. L., R. Gallagher, and J. R. Sjaarda. 1964. Serological typing of human lymphocytes with immune serum obtained after homografting. Science (Wash. D. C.). $144: 868$.

24. Morris, P. J., G. M. Williams, D. M. Hume, M. R. Mickey, and P. I. Terasaki. 1968. Serotyping for homotransplantation. XII. Occurrence of cytotoxic antibodies following kidney transplantation in man. Transplantation. $6: 392$.

25. Manzler, A. D. 1968. Serum cytotoxin in human kidney transplanted recipients. Transplantation. 6: 787.

26. Kretschmer, R., C. A. Janeway, and F. S. Rosen. 1968. Immunologic amnesia. Pediatr. Res. 2: 7.

27. Stastny, P., and M. Ziff. 1971. Direct lysis of lymphocytes by complement in patients with systemic lupus erythematosus. Arthritis Rheum. 14: 733.

28. Carter, R. L., and H. G. Penman. 1969. Haemolytic and other anemias in infectious mononucleosis. In Infectious Mononucleosis, The Oxford University Press, London. 5: 90 .

29. Dumonde, D. C., R. A. Walstencraft, G. S. Panayi, M. Matthew, J. Morley, and W. T. Howson. 1969. Lymphokines: Non-antibody mediators of cellular immunity generated by lymphocyte activation. Nature (Lond.). $224: 38$.

30. Notkins, A. L., S. E. Mergenhagen, and R. J. Howard. 1970. Effect of virus infections on the function of the immune system. Annu. Rev. Microbiol. 24: 525.

31. Dudding, B. A., S. C. Wagner, J. A. Zeller, J. T. Gmelich, G. R. French, and F. H. Top, Jr. 1972. Fatal pneumonia associated with adenovirus type 7 in three military trainees. N. Engl. J. Med. 286: 1289.

32. Oldstone, M. B. A., and F. J. Dixon. 1971. Tissue injury mediated by anti-viral antibody through a complement effector system. J. Immunol. 107: 1274. 